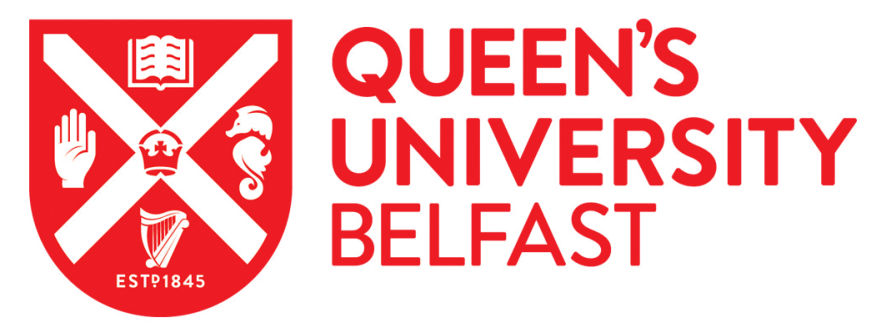

\title{
Conjunctive use of quantitative and qualitative X-ray diffraction analysis of soils and rocks for forensic analysis
}

Ruffell, A., \& Wiltshire, P. (2004). Conjunctive use of quantitative and qualitative X-ray diffraction analysis of soils and rocks for forensic analysis. Forensic Science International, 145(1), 13-23.

Published in:

Forensic Science International

Queen's University Belfast - Research Portal:

Link to publication record in Queen's University Belfast Research Portal

\section{General rights}

Copyright for the publications made accessible via the Queen's University Belfast Research Portal is retained by the author(s) and / or other copyright owners and it is a condition of accessing these publications that users recognise and abide by the legal requirements associated with these rights.

Take down policy

The Research Portal is Queen's institutional repository that provides access to Queen's research output. Every effort has been made to ensure that content in the Research Portal does not infringe any person's rights, or applicable UK laws. If you discover content in the Research Portal that you believe breaches copyright or violates any law, please contact openaccess@qub.ac.uk. 


\title{
Conjunctive use of quantitative and qualitative X-ray diffraction analysis of soils and rocks for forensic analysis
}

\author{
Alastair Ruffell $^{\mathrm{a}, *}$, Patricia Wiltshire ${ }^{\mathrm{b}}$ \\ ${ }^{a}$ School of Geography, Queen's University, Belfast BT7 1NN, N. Ireland, UK \\ ${ }^{\mathrm{b}}$ Institute of Archaeology, University College, London, Gower Street, London WC1E 6BT, UK
}

Received 1 September 2003; received in revised form 20 October 2003; accepted 9 March 2004

Available online 19 May 2004

\begin{abstract}
This paper describes a repeatability test, comparing conventional X-ray diffraction (XRD) analyses with the technique of quantitative X-ray diffraction (QXRD) as a determinant of mineral abundance. The conjunctive use of both methods allows specific mineral abundances to be matched between scene of crime (SOC) and suspects where soil or substrate mineralogy is similar. In our test, samples from potential SOC locations were taken from car tyre tracks. A car was driven to one location by an independent person and the car submitted for sampling. The tyre-tread sample showed potential correlation to two locations: one correct and the other incorrect. QXRD showed the mineral proportions of the tyre-tread sample matched only the correct location. However, QXRD did fail to discriminate two locations that XRD did show to be different. Both methods utilise the same sample and X-ray diffractogram, suggesting that their conjunctive use, preceded by standard Earth material forensic study, is recommended.
\end{abstract}

(C) 2004 Elsevier Ireland Ltd. All rights reserved.

Keywords: X-ray diffraction; Soil; Scene of crime; Tyre marks

\section{Introduction}

Established methods used in matching soil, building products and rock debris from scenes of crime to suspect's shoes, clothing, vehicles and houses include colour [1] and visual inspection of recovered debris. The use of the petrographic microscope significantly advanced geological applications to forensic science [2]. The use of the density gradient technique has undergone a simultaneous fall from favour [2]. Since the early 1990s, there has been a gradual increase in the range of analyses available to those marching SOC to suspects. GC-MS analysis for adipocere (decomposition lipid) [3] and methane [4]; particle-size analysis; [5]; Fourier transform infra-red spectroscopy (FTIR [6]); scanning electron microscopy (SEM [7]) and palynology [8] have all been used with varying success. X-ray powder

\footnotetext{
* Corresponding author. Tel.: +44-1232-273-407; fax: +44-1232-321-280.

E-mail address: a.ruffell@qub.ac.uk (A. Ruffell).
}

diffraction remains the best available technique for the identification of minerals in fine-grained materials such as soils, rock dust, building debris and rocks [9]. XRD identifies primary minerals (as opposed to chemicals or secondary chemicals) of a sample size that is often equivalent to typical recoveries from SOC and suspects [10]. Geochemical analyses such as XRF and ICP-MS or ICP-AES suffer from requiring too large a sample or being too detailed, the latter requiring multiple analyses to determine the typical composition [11,12]. Secondary determinants (adipocere, methane) suffer from problematic sampling, imprecise origin and complex suites of compounds with varied origins. Palynology is perhaps the closest technique to XRD in matching the natural SOC environment to suspect $[8,13]$. Up to 2001 [9], XRD comparison relied on matching the semi-quantitative presence of unique minerals or mineral assemblages. The QXRD technique [9] can now be deployed conjunctively with traditional mineral identification to give both statistical reliability in mineralogically similar soils, rocks, etc., as well as the possible detection of a unique mineral as a unique comparator [10]. 


\section{Methods}

\subsection{Traditional X-ray diffraction (XRD) analysis}

X-ray diffraction is a standard analytical technique in geological laboratories [14]. The method is particularly useful when studying fine-grained materials too small for easy identification by standard microscopy. The technique utilises a focussed X-ray beam $\sim 20 \mathrm{~mm}$ wide that is directed at varying angles onto a layer of material. The focussed $\mathrm{X}$ ray beam will be partly transmitted and partly diffracted by the molecular layers in the sample [14]. The angle of diffraction is dependent on the spacing of the molecules ( $d$-spacing): a simple equation (Bragg's law: $n \lambda=2 d \sin \theta$ ) calculates the $d$ spacing of the crystal (measured as 2-theta) from the angles of the incident diffracted beams. A diffraction is recorded by the beam detector and recorded as a peak on a chart (a diffractogram or XRD trace) of diffraction angle versus number of diffractions per angle (or part thereof) of beam incidence. Conventional XRD can be used to scan from as low as 1 or $2^{\circ}$, with $2^{\circ}$ being the convention. We have cut our XRD data at $5^{\circ}$ in order to facilitate easy comparison with the QXRD results. The position of peaks on an XRD trace can be semi-quantitatively matched to known standards to give mineral or crystalline substance determinations. The need to generate semiquantitative or quantitative information from XRD traces has generated some discussion [14]. The development of Rietveld analysis [15] and the QXRD technique [9] creates different output information in terms of the groups of minerals that can be identified. In this study, XRD has been used to discriminate 15 of the common minerals in the soils around Belfast $(\mathrm{N}$. Ireland). Greater or fewer minerals can of course be included. In this and previous studies, minerals with average abun- dances of $>2 \%$ have been excluded. Errors in the method can be generated by heterogeneous sampling, where an unusual grain may be introduced into a small sample.

\subsection{Quantitative $X$-ray diffraction $(Q X R D)$}

This technique [9] utilises peak intensity as a measure of wt.\% [10], based on rigorous wet (solvent) grinding of the sample in a McCrone Micronizing Mill (or equivalent) with $20 \mu \mathrm{m}$ sample grain-size output. A ZnO standard is added (its peak can be removed from the resultant diffractogram); the sample is kept homogenous by side-loading of the sample tray. The same recording conditions as the XRD method are then applied, using a Siemens D-5000 diffractometer (Fig. 1) that generates $\mathrm{Cu} \mathrm{K} \alpha$ radiation. Conventional XRD makes use of all the peaks generated from a specific mineral: QXRD uses only the 060 crystal axis peak [9]. Peak intensity is then measured, with any appropriate adjustments where peaks overlap [10]. QXRD has been used to quantify 14 minerals, of which 8 are common to the XRD technique. This makes the two methods, following the same sampling and XRD examination procedure, useful as a comparative methodology. An extension of the traditional XRD technique is analysis of the clay mineral $<2 \mu \mathrm{m}$ fraction of a sample $[2,14]$. This aspect is not discussed here. Loss on ignition (LOI) was also performed by heating the weighed diffraction powders to $700{ }^{\circ} \mathrm{C}$ for $45 \mathrm{~min}$ following $\mathrm{X}$-ray analysis.

\section{A test of the methods}

In order to test whether a sample of unknown origin could be reliably matched to a possible source, some
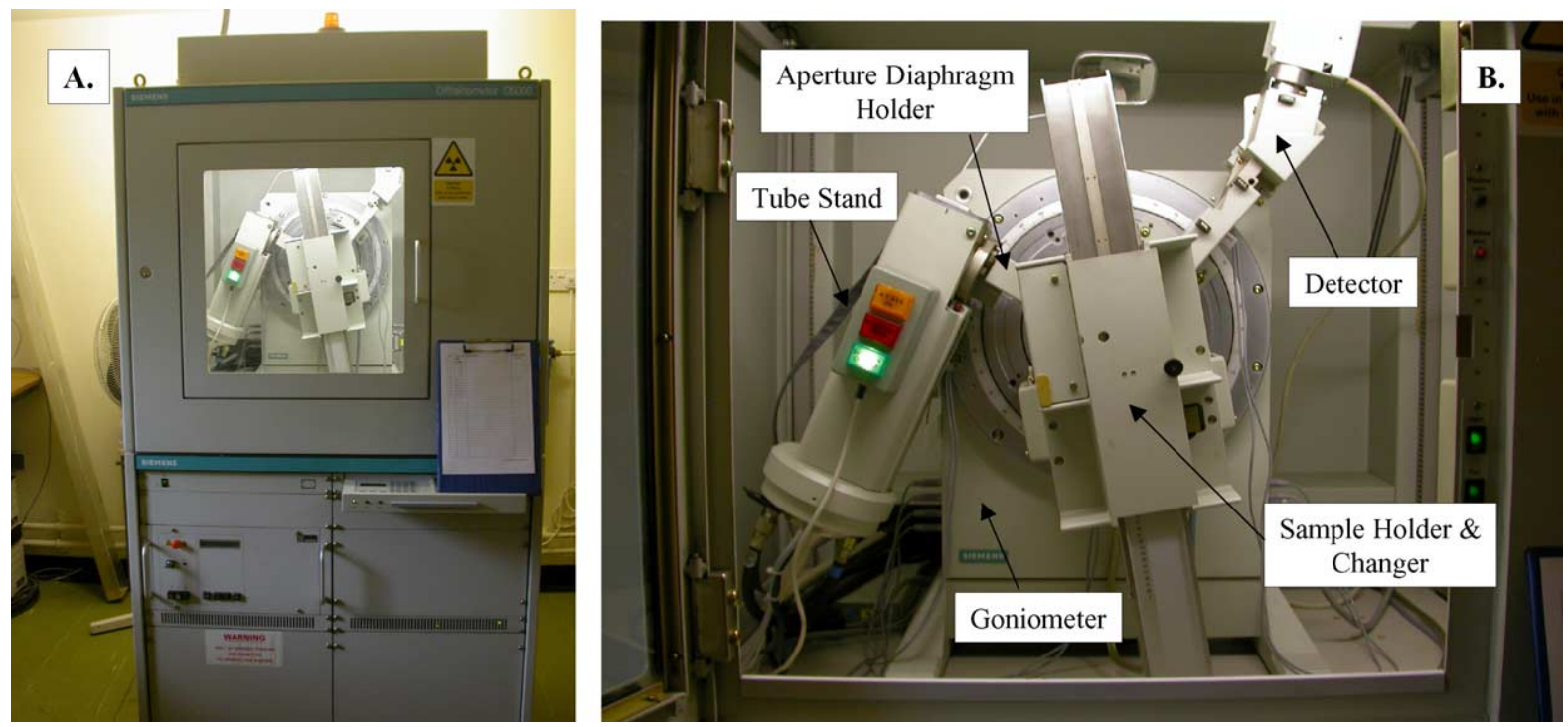

Fig. 1. The Siemens D-5000 diffractometer, as used in this study. (A) Overview of the machine, showing the generator units (below) and the diffractometer (above); (B) detail of the diffractometer. 
sensible parameters were introduced. The range of mineral types in soil may be upwards of tens to hundreds as there are over 2200 known natural minerals [2]. Thus, a random sample cannot be analysed and its provenance matched to a map of soil distribution. In this case study of forensic use, matching of an unknown sample to possible sources provides a useful test. In the case of a unique mineral linking suspect to SOC [2], then this method serves merely as confirmation of a link. However, rare minerals are not always present, so a robust method of sample matching the common minerals (such as QXRD) is required.

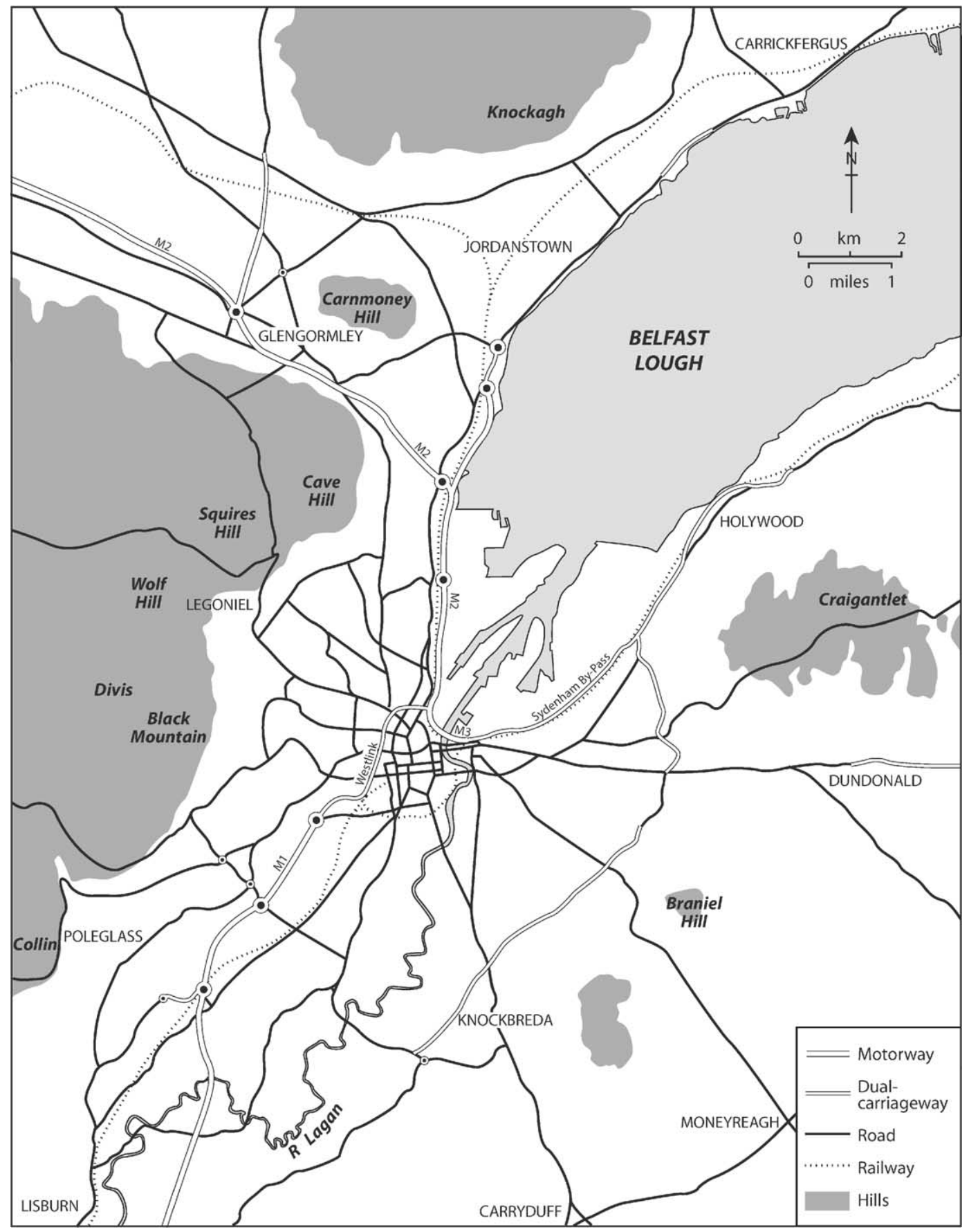

Fig. 2. Map of the sample locations in the greater Belfast area (N. Ireland). Sample locations are all areas with loose, generally fine-grained roadways. The test site is location 18 . 
Table 1

Sample locations in the greater Belfast area (N. Ireland)

\begin{tabular}{llll}
\hline Sample number & Abbreviated & Location & Grid reference \\
\hline AR1 & Basalt soil & Woodburn, N. Belfast & 369882 \\
AR2 & Basalt soil & Blackmountain, W. Belfast & 287724 \\
AR3 & Red sandy soil & Dunmurry & 291691 \\
AR4 & Soil on sandstone & Lambeg & 280674 \\
AR5 & Mudstone soil & Legoniel Car Park & 304777 \\
AR6 & Mudstone soil & Carnmoney Cemetary & 329816 \\
AR7 & Greywacke soil & Purdysburn & 345677 \\
AR8 & Greywacke soil & Roselawn Cemetary & 387702 \\
AR9 & Limestone soil & laneway, Holywood & 400795 \\
AR10 & Dolerite soil & Dundonald & 412729 \\
AR11 & Estuarine clay & Whitehouse & 348808 \\
AR12 & Organic clay & Holywood Boat Club & 385779 \\
AR13 & Boulder clay soil & Monkstown & 345845 \\
AR14 & Boulder clay soil & Andersonstown & 297725 \\
AR15 & Organic boulder clay & Blackmountain Quarry & 302782 \\
AR16 & Oil soil & Docks Scrap Yard & 361761 \\
AR17 & Fluvial silt & Milltown Graveyard & 312725 \\
AR18 & Sandy esker & Ballynahatty & 325682 \\
AR19 & Peat silt & Ballynahatty & 325682 \\
AR20 & Landfill & Landfill site & 345770 \\
AR21 & Chalk soil & Ballygomartin & 285761
\end{tabular}

Sample locations are all areas with loose, generally fine-grained roadways. The test site is location 18 .

A standard saloon car (Ford Mondeo) with moderately worn tyres (5000 mile usage) was driven to 21 different unmetalled lanes, car parks and driveways in the greater Belfast area (Fig. 2 and Table 1) over a 2-day period. Late
May was chosen as a time of moderate precipitation and temperature. A mobile jet-hose was used to clean the vehicle after each site was visited. At each lane, the vehicle was driven in and then reversed. In these climatic conditions, no
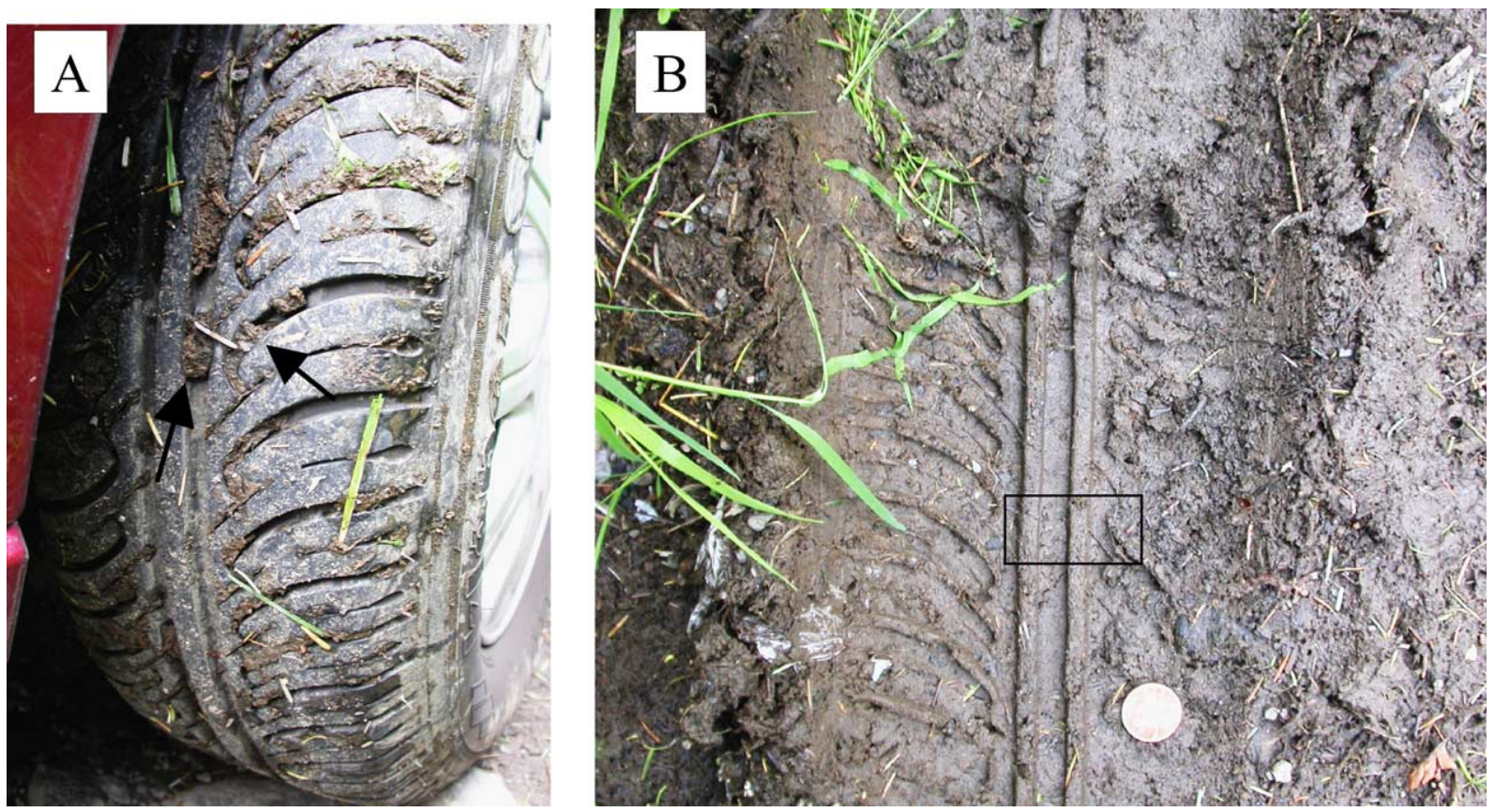

Fig. 3. Sample locations from (A) the test sample (tyre-tread locations) and from (B) a typical tyre impression mark (location AR18), showing the size and location of sample (coin is a UK 2 pence, $2.5 \mathrm{~cm}$ diameter). 

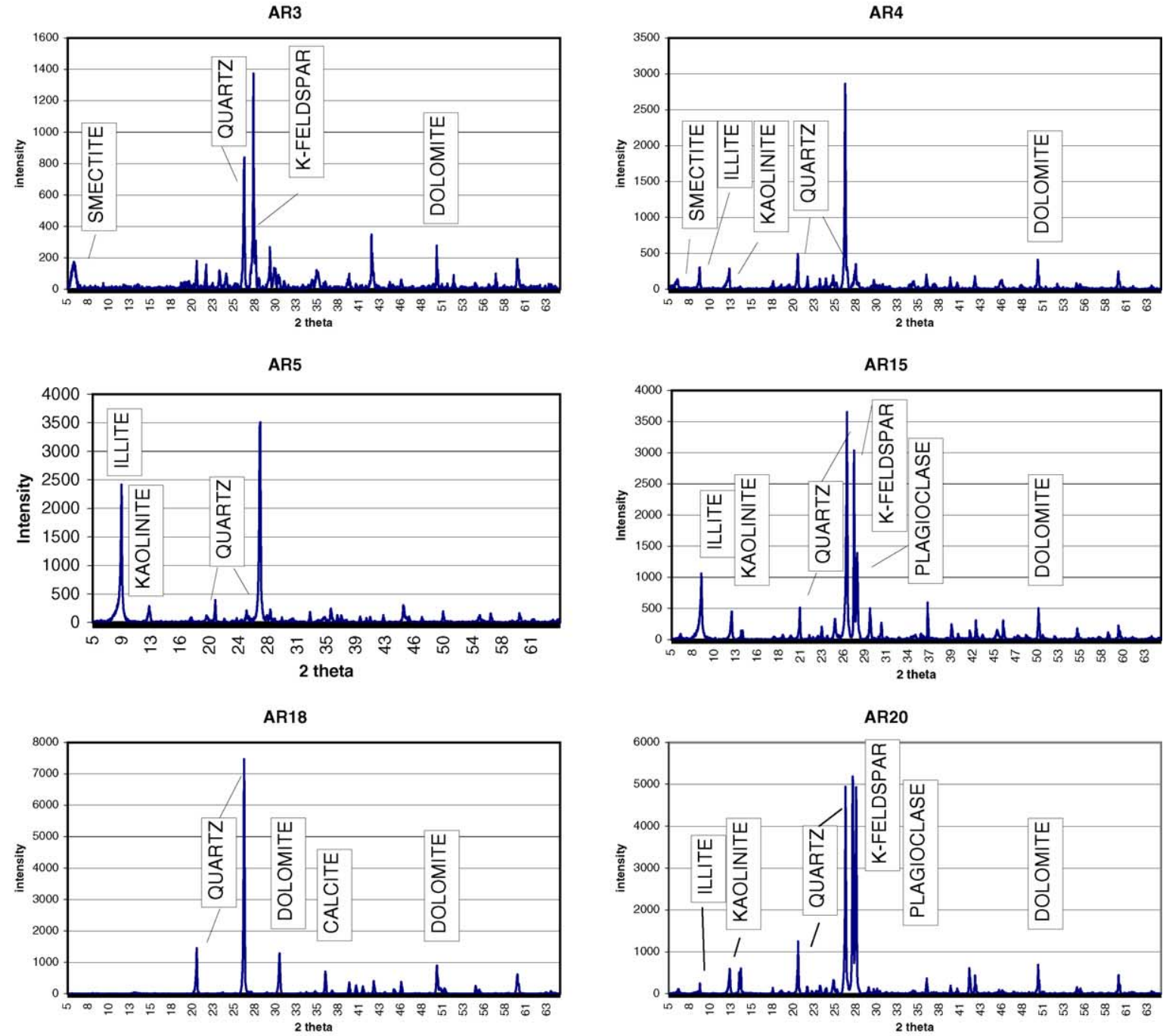

TEST

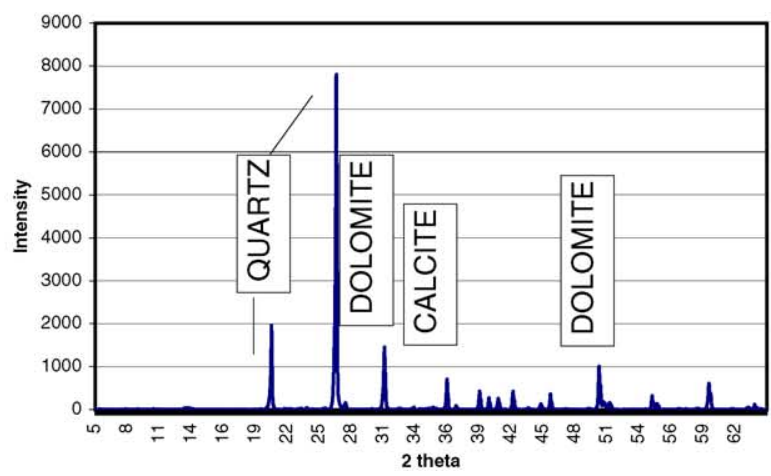

Fig. 4. Selected X-ray diffractograms from the sample set used in this study. The output and mineral identifications are those used in the QXRD method. The test sample was generated from a car tyre 2 miles after having been driven over site 18 (a sandy esker soil in South Belfast). 
Table 2

Summary conventional XRD and loss on ignition (LOI) data of the main mineral types found in samples taken for this study

\begin{tabular}{|c|c|c|c|c|c|c|c|c|c|c|c|c|c|c|c|c|c|c|}
\hline $\begin{array}{l}\text { Sample } \\
\text { number }\end{array}$ & Quartz & Albite & Anorthite & Microcline & Muscovite & Biotite & Illite & Hornblende & Kaolinite & Chlorite & Montmorillonite & Siderite & Calcite & Dolomite & Hematite & $\begin{array}{l}\text { LOI } \\
(\%)\end{array}$ & Total (\%) & \\
\hline AR1 & 2.22 & 1.2 & 1.43 & 0.51 & 6.5 & 0.54 & 4.5 & 3.2 & 14.3 & 1.1 & 37.8 & 6.6 & 1.2 & 0 & 7.5 & 10 & 98.7 & Basalt soil \\
\hline AR2 & 4.45 & 2.12 & 0.4 & 1.2 & 3.3 & 1.2 & 5.4 & 2.7 & 11.2 & 1 & 34.6 & 7.8 & 2.1 & 0.5 & 7 & 12 & 97.27 & Basalt soil \\
\hline AR3 & 23 & 21 & 11 & 8 & 2.6 & 1.4 & 1.8 & 0 & 0.4 & 0 & 14.5 & 0 & 2.3 & 0 & 1.2 & 9 & 96.2 & Red sandy soil \\
\hline AR4 & 41.5 & 4 & 0 & 2.3 & 2.2 & 1.09 & 3.7 & 1.5 & 4.5 & 1.1 & 3.4 & 0.6 & 2.1 & 7 & 0.6 & 20 & 95.66 & Soil on sandstone \\
\hline AR5 & 40.2 & 3.3 & 0 & 4.4 & 4.6 & 1.3 & 23 & 0.8 & 7 & 2.4 & 0 & 1 & 3 & 0 & 0 & 3.3 & 94.1 & Mudstone soil \\
\hline AR6 & 22.3 & 1.5 & 1.1 & 1.2 & 5.8 & 0.6 & 16 & 0 & 3.4 & 0.7 & 9 & 3.67 & 4.4 & 6.7 & 3.3 & 13 & 92.67 & Mudstone soil \\
\hline AR7 & 23.5 & 7.34 & 3.4 & 1.4 & 10.4 & 1.1 & 9.6 & 0.5 & 1.1 & 12.5 & 3.7 & 1.3 & 0.45 & 0.22 & 1.1 & 17 & 94.61 & Greywacke soil \\
\hline AR8 & 23 & 8.7 & 3 & 3.5 & 9.8 & 2.5 & 11 & 1.5 & 2.43 & 10.4 & 1.2 & 1.4 & 2.1 & 0 & 1.3 & 13 & 94.83 & Greywacke soil \\
\hline AR9 & 18.7 & 2 & 1.3 & 0.1 & 6.89 & 2 & 14 & 0 & 3.5 & 1.45 & 11.4 & 5.7 & 8.76 & 4.67 & 6.6 & 9.8 & 96.37 & Limestone soil \\
\hline AR10 & 6.7 & 2.1 & 5.7 & 6.7 & 5.6 & 9.98 & 4.4 & 4.5 & 6.5 & 2.2 & 23.3 & 3 & 4.6 & 1.5 & 0.41 & 13 & 100.2 & Dolerite soil \\
\hline AR11 & 18.7 & 0 & 0 & 0.5 & 0 & 1.1 & 4.7 & 0 & 3.2 & 4.7 & 35.6 & 3.5 & 5.5 & 3.6 & 1.3 & 14 & 96.17 & Estuarine clay \\
\hline AR12 & 21 & 0 & 0 & 0 & 2.3 & 1.3 & 2.6 & 0.8 & 4.7 & 4.4 & 34.6 & 5.6 & 4.4 & 0.67 & 3.4 & 9.8 & 95.57 & Organic clay \\
\hline AR13 & 23.4 & 1 & 2.3 & 0 & 0 & 1.1 & 6.7 & 0.7 & 3.4 & 8.7 & 12.4 & 3.5 & 0.9 & 1.1 & 1.4 & 34 & 100.1 & Boulder clay soil \\
\hline AR14 & 23.5 & 0 & 2.5 & 0.67 & 1.2 & 3.4 & 7.8 & 1.1 & 6.7 & 5.6 & 14.6 & 3.3 & 4.5 & 1.6 & 2.3 & 20 & 98.35 & Boulder clay soil \\
\hline AR15 & 33 & 9 & 1.89 & 0 & 2 & 1.2 & 9.8 & 0 & 3 & 1.1 & 1.3 & 1.5 & 3.4 & 4 & 1.3 & 15 & 87.59 & $\begin{array}{l}\text { Organic boulder } \\
\text { clay }\end{array}$ \\
\hline AR16 & 28.6 & 1.45 & 0 & 0.89 & 2.5 & 0 & 3.5 & 2 & 3.5 & 1.4 & 23 & 4.5 & 2.5 & 1.2 & 0.8 & 23 & 98.34 & Oil soil \\
\hline AR17 & 13.5 & 1.6 & 0 & 2.4 & 0 & 0.4 & 2.7 & 0.9 & 17.8 & 3.4 & 23.67 & 2.2 & 4.3 & 5 & 4.6 & 15 & 96.94 & Fluvial silt \\
\hline AR18 & 62.4 & 0 & 0 & 1 & 1.2 & 0 & 0 & 2 & 1 & 0 & 0 & 2 & 4.5 & 9.6 & 1.67 & 9.8 & 95.17 & Sandy esker \\
\hline AR19 & 7.67 & 1.6 & 0 & 0 & 2.5 & 1.1 & 10 & 0 & 5 & 4.6 & 13.78 & 0 & 3.6 & 2.4 & 2.6 & 35 & 89.43 & Peat silt \\
\hline AR20 & 18.7 & 12 & 7 & 3 & 4.3 & 1.3 & 2.4 & 4 & 5.78 & 1.6 & 1.2 & 3.2 & 0 & 5.6 & 1 & 23 & 94.11 & Landfill \\
\hline AR21 & 23 & 0 & 0 & 0 & 2.1 & 1.3 & 13 & 0 & 4 & 2.24 & 12.7 & 5.5 & 17.65 & 1.6 & 2.4 & 13 & 98.09 & Chalk soil \\
\hline Test & 60 & 0 & 0 & 1 & 2 & 0 & 0 & 3 & 1 & 0 & 0 & 2 & 5 & 10 & 2.5 & 9.8 & 96.3 & Unknown \\
\hline
\end{tabular}

The unknown test (car tyre) sample is from location AR18. 
tyre imprint was greater than $1 \mathrm{~cm}$ deep, thus avoiding the necessity for stratigraphic-based sampling of the imprint. A $10 \mathrm{~g}$ sample from a layer across either one or two tyre marks (depending on location of mud imprints) was taken with a disposable spatula [2,5]. The area sampled was $5 \mathrm{~cm}$ across, $2 \mathrm{~cm}$ wide and $1 \mathrm{~cm}$ deep. Total weight of the sample thus varied, depending on rock, soil, organic and other content. If the tyre mark left any individual prints such as cuts to the rubber, areas of uneven wear, embedded stones, then these were chosen as the sample points. Sampling of soil for XRD can take place following plaster casting, if required, as any gypsum residue will be easily identified in the X-ray diffractogram. The same area and type of sample was taken from both sets of tyre tracks (where made) and logged with an identification number. After the vehicle was driven 2 miles from one random sample location, the embedded mud was picked from the tyre using a clean dental pick (Fig. 3). This location was not known to the authors. After this, and immediately prior to all other site visits, the tyres were rotated and jet-washed until visually free of debris.
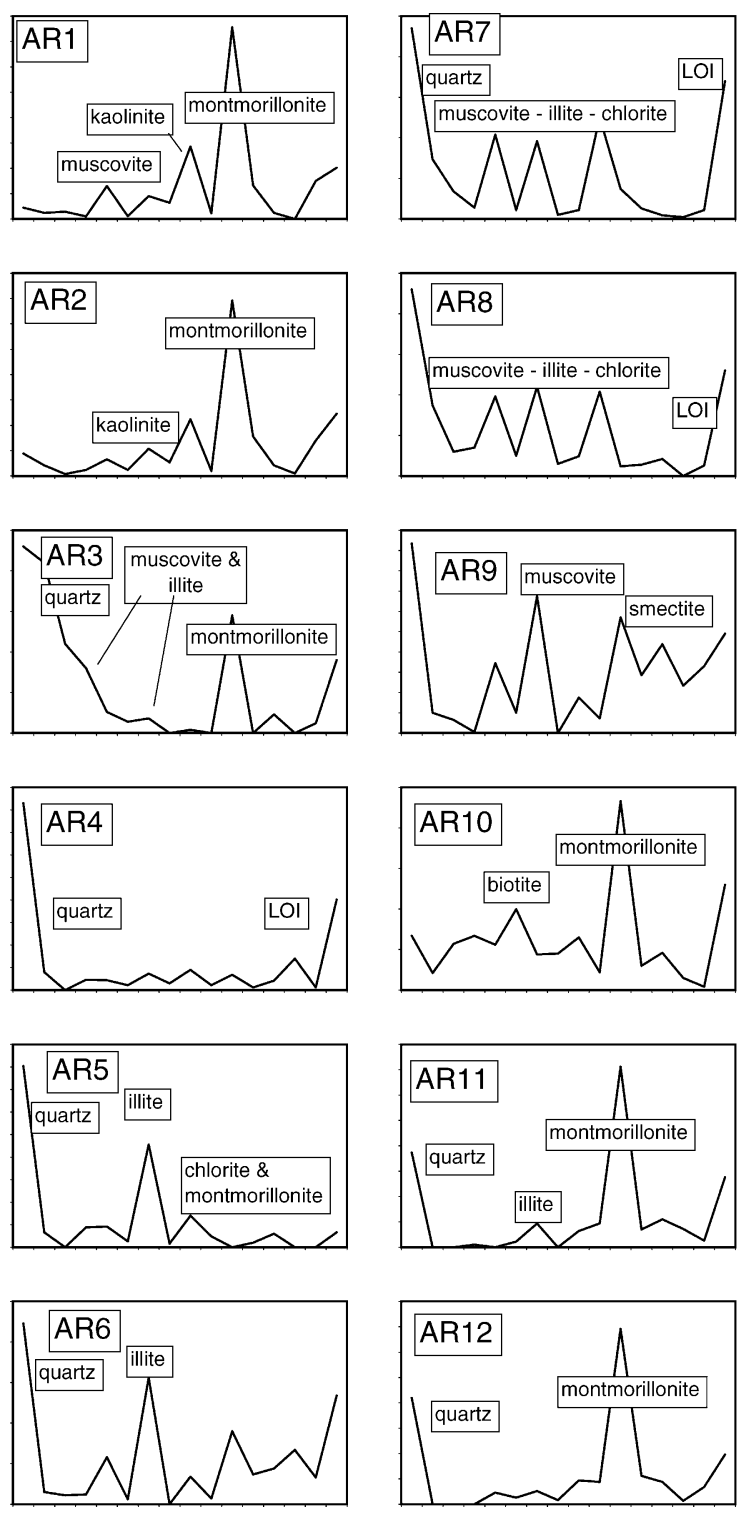
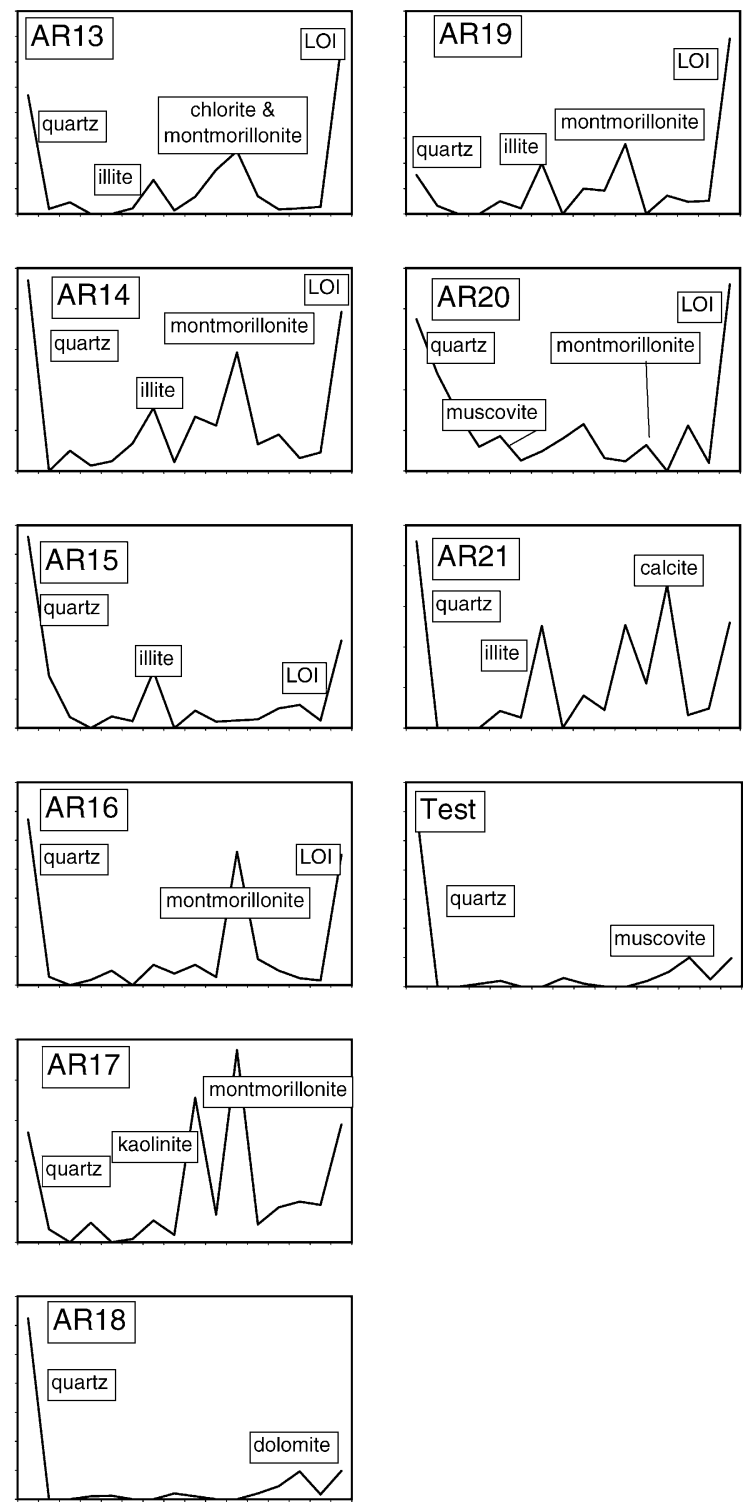

Fig. 5. Simple abundance plots of the minerals identified and quantified by XRD. These confirm the PCA analysis of samples 7 and 8,4 and 18 , and 5 and 15 (the latter discounting loss on ignition or LOI data) as being comparable. The unkown test data were derived from the car tyre 2 miles after being driven over sample site 18 . 
Table 3

Summary QXRD and loss on ignition (LOI) data of the main mineral types found in samples taken for this study

\begin{tabular}{|c|c|c|c|c|c|c|c|c|c|c|c|c|c|c|c|c|c|}
\hline $\begin{array}{l}\text { Sample } \\
\text { number }\end{array}$ & Quartz & Kspar & Plag & Calcite & Mg-calcite & Dolomite & Gypsum & Siderite & Pyrite & Hematite & Kaolinite & $\begin{array}{l}\text { Illite } \\
\text { 2:1Al }\end{array}$ & Chlorite & $\begin{array}{l}\text { Smectite } \\
2: 1 \mathrm{Fe}\end{array}$ & $\begin{array}{l}\text { LOI } \\
(\%)\end{array}$ & & \\
\hline AR1 & 3.01 & 1.67 & 2.5 & 2.1 & 1.98 & 0 & 2.2 & 6.5 & 0 & 9 & 12.45 & 5.5 & 1 & 37 & 10 & 95.01 & Basalt soil \\
\hline AR2 & 5.5 & 1.2 & 0.5 & 2.5 & 4.5 & 1 & 1.1 & 6.67 & 0 & 11.7 & 12.1 & 4.23 & 2 & 34.5 & 12 & 99.8 & Basalt soil \\
\hline AR3 & 22 & 27 & 5.5 & 2.45 & 3.5 & 6.5 & 1 & 1.56 & 2 & 2.06 & 0 & 1.8 & 0 & 14 & 9 & 98.37 & Red sandy soil \\
\hline AR4 & 40 & 0 & 4.3 & 3.4 & 0 & 5.3 & 3.4 & 2.4 & 0 & 1.3 & 3.3 & 6.35 & 0 & 2.2 & 20 & 92.05 & Soil on sandstone \\
\hline AR5 & 45 & 6 & 0 & 2 & 0 & 0 & 0 & 2 & 3.4 & 0 & 6.7 & 24.5 & 3.8 & 0 & 3.3 & 96.7 & Mudstone soil \\
\hline AR6 & 19.65 & 2.5 & 0 & 5.6 & 4.8 & 3.6 & 3.34 & 3.5 & 2 & 1.08 & 7.45 & 13.6 & 1.1 & 10.1 & 13 & 91.72 & Mudstone soil \\
\hline AR7 & 35 & 11.2 & 4 & 1.4 & 0.5 & 0 & 0 & 1.09 & 2.3 & 1.04 & 3.4 & 11.4 & 9 & 2.45 & 17 & 99.78 & Greywacke soil \\
\hline AR8 & 26.7 & 11 & 2 & 2.1 & 10 & 0 & 0.4 & 3.09 & 2.3 & 3.01 & 2.5 & 12.3 & 8.8 & 1.76 & 13 & 98.96 & Greywacke soil \\
\hline AR9 & 22.7 & 1 & 1 & 12.03 & 3.2 & 4 & 0 & 3.5 & 2.2 & 2 & 7.6 & 14.6 & 3.3 & 10.3 & 9.8 & 97.23 & Limestone soil \\
\hline AR10 & 7.77 & 2 & 3.5 & 1 & 5.7 & 4.4 & 0 & 2.3 & 1.5 & 2.2 & 9.8 & 5.5 & 4.67 & 36.4 & 13 & 99.69 & Dolerite soil \\
\hline AR11 & 11.72 & 0 & 1 & 5.8 & 2.2 & 5.6 & 1 & 2.1 & 2.3 & 1 & 3.3 & 4.03 & 5.5 & 35.55 & 14 & 94.9 & Estuarine clay \\
\hline AR12 & 19 & 2 & 1 & 0.5 & 4 & 1.2 & 3 & 6 & 2.7 & 3.67 & 4.56 & 2.5 & 3.4 & 33.2 & 9.8 & 96.53 & Organic clay \\
\hline AR13 & 16.8 & 2 & 2.5 & 1.3 & 1 & 1 & 2.23 & 3.3 & 4.3 & 0 & 3.2 & 7.6 & 7.78 & 15.6 & 30 & 98.91 & Boulder clay soil \\
\hline AR14 & 17.8 & 0 & 3.1 & 3.5 & 1 & 3.5 & 2.2 & 3 & 4.67 & 2.22 & 7.88 & 7.54 & 5.5 & 17.7 & 20 & 99.21 & Boulder clay soil \\
\hline AR15 & 31.1 & 18 & 8 & 3.5 & 1 & 2 & 1.65 & 1.3 & 2.1 & 1 & 2.3 & 9 & 1.23 & 1.9 & 15 & 99.18 & $\begin{array}{l}\text { Organic boulder } \\
\text { clay }\end{array}$ \\
\hline AR16 & 21.5 & 0 & 2 & 2.2 & 2.1 & 2 & 2.1 & 5.5 & 0 & 1 & 2.65 & 5.6 & 1.5 & 30.1 & 23 & 100.8 & Oil soil \\
\hline AR17 & 14 & 0 & 0 & 2.53 & 3 & 3.7 & 4.5 & 3.4 & 2 & 3.2 & 15.77 & 5 & 5.6 & 20.09 & 15 & 97.29 & Fluvial silt \\
\hline AR18 & 63.19 & 0 & 0 & 2.54 & 1 & 8.4 & 2 & 3 & 0 & 2.1 & 2.7 & 0 & 0 & 0 & 9.8 & 94.73 & Sandy esker \\
\hline AR19 & 9 & 3 & 2 & 5.6 & 1.91 & 4.7 & 2 & 1.02 & 2 & 4.44 & 6.4 & 8.49 & 3.59 & 12.4 & 35 & 101.1 & Peat silt \\
\hline AR20 & 15.7 & 16.5 & 14 & 1.2 & 3.32 & 5 & 2.1 & 1 & 2 & 3.32 & 5.56 & 3.45 & 1.6 & 1.4 & 23 & 98.65 & Landfill \\
\hline AR21 & 18.76 & 1 & 1 & 12 & 2.21 & 1 & 0 & 2 & 2 & 2.2 & 3.5 & 12 & 4.2 & 14.5 & 13 & 89.37 & Chalk soil \\
\hline Test & 64 & 0 & 0 & 4 & 1 & 9 & 1 & 3 & 0 & 2 & 3.1 & 0 & 0 & 0 & 9.8 & 96.9 & Unknown origin \\
\hline
\end{tabular}

The unknown test (car tyre) sample is from location AR18. 
From 21 laneways, 42 samples were generated as the locations to be matched. The resultant samples were split and subject to XRD and QXRD using the procedures outlined above. The results from each tyre of the same laneway were similar enough that for brevity they are presented together: typical X-ray diffractograms are shown in Fig. 4. The split dataset is available from the author on request. Apart from the unknown test soil, all samples were collected by the same person (A.R.) and placed in pristine plastic bags. Each sample was dried in 5-cm deep ceramic vessels in a laboratory oven for $6 \mathrm{~h}$ at $80^{\circ} \mathrm{C}$. They were taken separately to a clean preparation room, crushed and ground using the procedures described above. All utensils were double-cleaned with acetone and new laboratory tissue. Powders were placed in clean plastic holders and analysed in the XRD machine (see above) over a 3-day duration by a technician. Chain of custody [16] was two people for all known samples and three people for the control. All sampling, preparation and analytical procedures were otherwise identical for all samples. From sampling to result comparison, the dataset presented below took five working days to generate, with considerable time saved through the use of the same X-ray diffractograms for the XRD and QXRD analyses. A match of two samples and a control would take $24 \mathrm{~h}$.
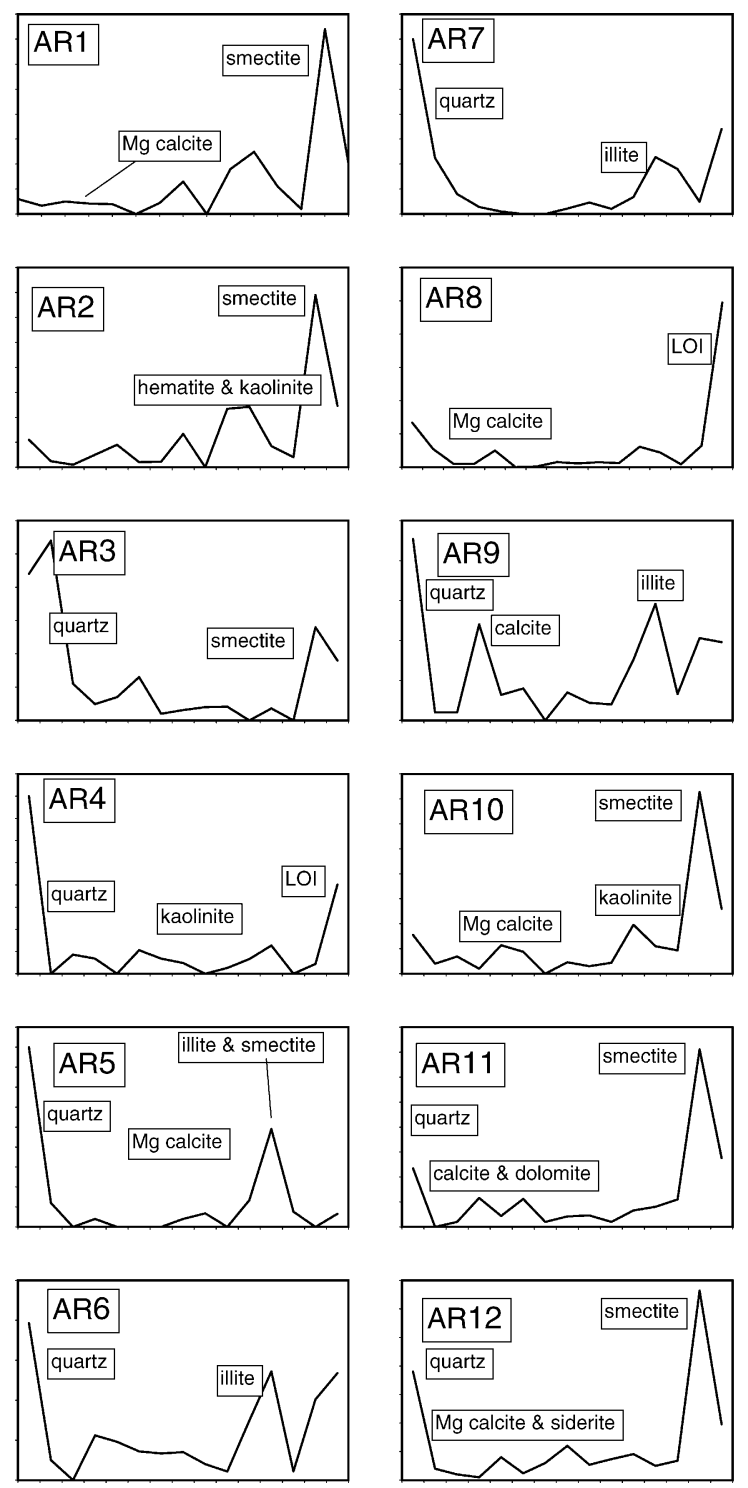
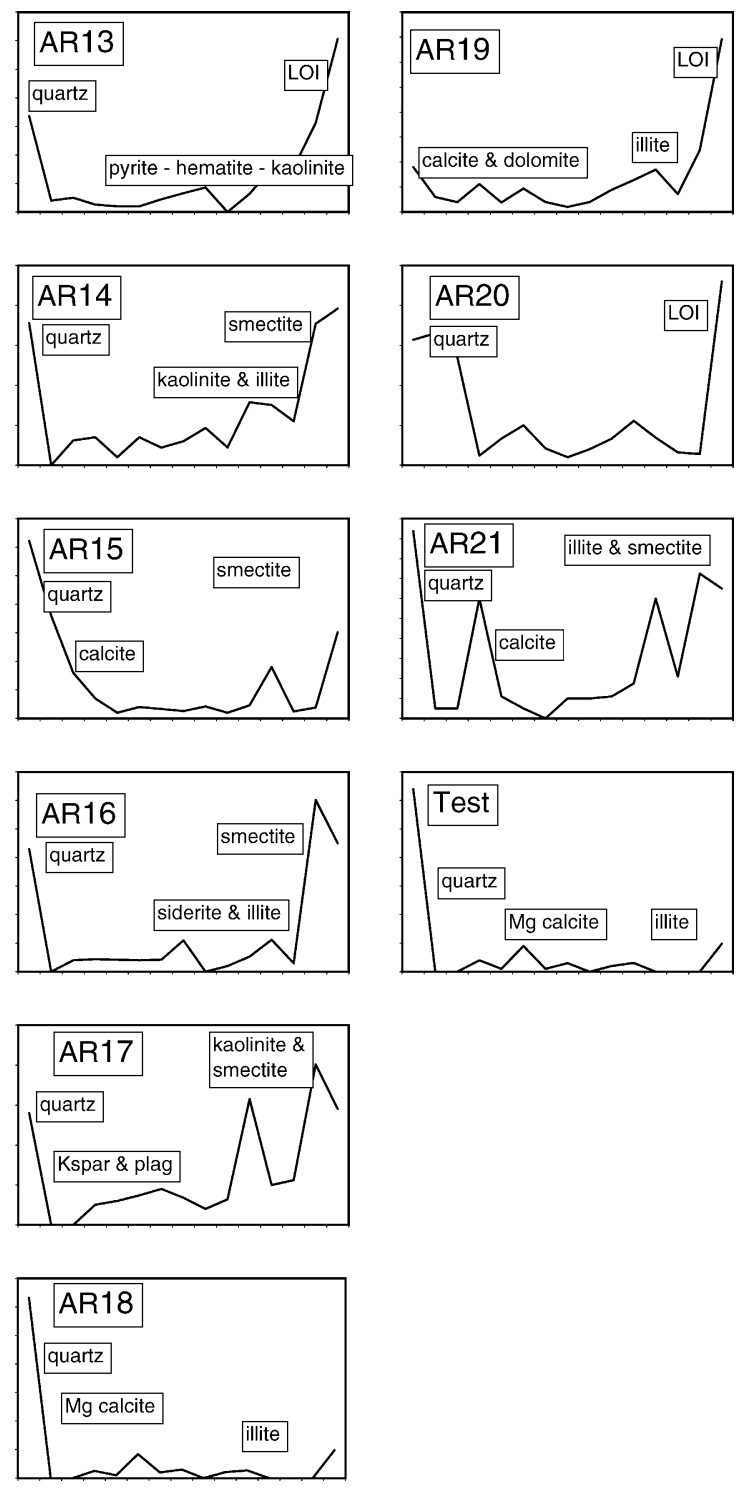

Fig. 6. Simple abundance plots of minerals identified and quantified by QXRD. These, compared to PCA analysis show samples 9 and 21 to be possible comparators, as well as sample 18 and the unknown test sample. 


\section{Results}

\subsection{XRD}

Results from the conventional XRD method are presented in Table 2, with unusual minerals excluded as we wish to test the more problematic case of homogenous soil sample comparison. Such tables of data provide a mass of information that has to be assessed with regard to two judgements: first, which geological materials are considered to occur in unique enough quantities in the environments sampled to provide positive comparison? second, which samples are statistically most alike and most different? Principal component analysis (PCA [17]) was employed in order to discriminate samples with both an abundance of one mineral or group of minerals over those in the other samples. Our combined data analysis (above) shows samples 7 and 8, 4 and 18 , and 5 and 15 to be similar with low variation (eigenvalues) in the mineral abundances (loss on ignition values were excluded as organic matter content is not strictly comparable to mineral content in all cases). Simple plots of abundance can demonstrate visually what the numerical data analysis is highlighting, as well as providing a visual comparison of the data (Fig. 5). These plots can be generated very quickly from spreadsheets such as Excel $^{\mathrm{TM}}$ and SPSS $^{\mathrm{TM}}$. They show samples 7 and 8 to be similar; in addition, samples 4 or 18 could be the match for the test sample. PCA [17] of the data in Table 2 highlights the presence of dolomite in sample 18 that is unique enough for discrimination. Geological common sense shows that although the abundances of albite, microcline, muscovite, biotite, illite and montmorillonite are small in sample 4 and often absent in the test tyre sample, the combination of these minerals is unlikely to be a random occurrence.

\section{2. $Q X R D$}

Table 3 shows the output from the QXRD technique, as deployed on the same X-ray diffractograms as the conventional XRD method (above) but utilising the 060 crystal reflections. Thus, there are some of the same minerals identified in both methods, plus some identifications of the same mineral are based on their crystal structure. Montmorillonite in Table 2 (XRD) is the same mineral as smectite 2:1 Fe clay in the majority of samples in Table 3 (QXRD). Our analysis of the data identifies two sample matches: 9 and 21, and 11 and 12. Visual comparison of the data (Table 3), as well the simple plots of abundance (Fig. 6), shows that 11 and 12 are actually distinct by virtue of the quartz, K-feldspar and Mg calcite content. Samples 9 and 21 do, however, show possible confusion as only the calcite abundance serves as a discriminant. Calcite is soluble and thus not a good mineral on which to base comparisons. The confusion between samples 7 and 8 that was generated by the XRD method (above) is now resolved as QXRD has shown the greater proportion of illite and $\mathrm{Mg}$ calcite. Similarly, the possible match of sample 4 to the unknown test sample is now eliminated: on the basis of QXRD, only sample 18 can be positively matched to the test. If either sample 9 or 21 had happened to be the test, then QXRD would not have provided the discriminant.

\section{Conclusions}

Both conventional XRD and QXRD were successful in matching a known laneway soil (both tyre marks) to the unknown test tyre sample. PCA analysis showed that XRD analysis of sample 4 also showed a possible correlation to the tyre sample. However, geological common sense shows this to be a product of low abundance versus absence. XRD analysis generated three possible matched samples as well as two possible matches for the unknown tyre test sample. QXRD produced only two matches, one incorrect and the other a match of the tyre sample to its correct provenance. In this regard, QXRD out-performed XRD, but the chance element demonstrates that if samples 9 or 21 had been the unknown tyre sample, then XRD would have been preferred to QXRD. This is because QXRD made similar measurements of calcite abundance (a soluble and thus unreliable mineral in most cases) in two samples that were differentiated by XRD.

Given that the test laneway is on similar geological parent rock to three other samples sites, in equivalent topographic locations, this high level of accuracy demonstrates the conjunctive use of the techniques. However, the two XRD identical samples do not provide convincing trace evidence for presentation in court. Whilst QXRD generates accurate and reproducible results, the method is dependent on having a minimum sample size of $2 \mathrm{~g}$. Smaller amounts of trace evidence such as clothing brushings or fingernail extractions do not produce sufficient material for the QXRD used here [9]. The fundamental problem is one of initial sample size [18]: a few grains of silt or fine sand cannot be quantitatively characterised by QXRD. Matching such small sample sizes falls back on conventional XRD, petrographic microscope or may require trace element or stable isotopic analysis.

Two recommendations arise from this work.

1. The use of the same sample and analytical procedure in QXRD and XRD demonstrates that accuracy is improved at minimal extra time or financial cost when the two methods are used in conjunction. This is because the techniques measure some of the same minerals (allowing validation) as well as some unique minerals (allowing comparison). The flow diagram showing examination sequence devised by Skip Palenik [2] recommends using XRD in special problems, presumably because the technique is suited to the identification of clay-sized $(2 \mu \mathrm{m})$ unique minerals. The conjunctive use of XRD and QXRD may suggest elevation of the 
method to part of the standard analytical procedure that uses the petrographic microscope when soils, finegrained rock and building dust are analysed.

2. In future tests of this method, should deeply incised tyre marks be sampled, the location of the tread sample must be matched to the location of the sample from the tyre mark. This is because there may be micro-stratigraphic variations on the scale of a few centimetres that could cause enough variation between the shallow edge and deep centre of the tyre mark to affect the XRD and QXRD output [18].

\section{Acknowledgements}

Thanks to David Rendle, Brian Lavery, Duncan Pirrie and Jim Spears for their help in discussion. John Meneely conducted the XRD analysis.

\section{References}

[1] Y. Marumo, R. Sugita, Validity of color examination for forensic soil identification, Forensic Sci. Int. 83 (1996) 201210.

[2] R.C. Murray, J.C.F. Tedrow, Forensic Geology, Prentice Hall, Englewood Cliffs, 1992, 156 pp.

[3] N. Cabriola, M.T. Pommier, M. Gueux, G. Payen, Comparison of lipid composition in two types of human peutrfactive liquid, Forensic Sci. Int. 94 (1998) 47-54.

[4] A. Ruffell, Remote detection and identification of organic remains: an assessment of archeological potential, Archaeol. Prospect. 9 (2002) 115-122.

[5] Y. Marumo, R. Sugita, Screening of soil evidence by a combination of simple techniques: validity of particle size distribution, Forensic Sci. Int. 122 (2001) 155-158.
[6] R.J. Cox, H.L. Peterson, J. Young, C. Cusik, E.O. Espinoza, The forensic analysis of soil organic by FTIR, Forensic Sci. Int. 108 (2000) 107-116.

[7] M.J. McVicar, W.J. Graves, The forensic comparison of soils by automated scanning electron microscopy, Can. Soc. Forensic Sci. J. 30 (1997) 241-261.

[8] M. Horrocks, S.A. Coulson, K.A.J. Walsh, Forensic palynology: variation in the pollen content of soil on shoes and in shoeprints in soil, J. Forensic Sci. 44 (1999) 119-122.

[9] J. Srodon, V.A. Drits, D.K. McCarty, J.C.C. Hsieh, D.D. Eberl, Quantitative X-ray diffraction analysis of clay-bearing rocks from random preparations, Clays Clay Miner. 49 (2001) 514-528.

[10] D. Righi, F. Elsass, Characterization of soil clay minerals: decomposition of X-ray diffraction diagrams and highresolution electron microscopy, Clays Clay Miner. 44 (1996) 791-800.

[11] M.R. Cave, J. Wragg, Measurement of trace element distributions in soils and sediments using sequential leach data and a non-specific extraction system with chemometric data processing, Analyst 122 (1997) 1211-1221.

[12] Interpol Forensic Science Symposium, Lyon, France, October 16-19, 2001.

[13] J.H. Bock, D.O. Norris, Forensic botany: an under-utilized resource, J. Forensic Sci. 42 (1997) 364-367.

[14] M.E. Tucker, Techniques in Sedimentology, Blackwell Scientific Publications, 1988, 394 pp.

[15] H.M. Rietveld, A profile refinement for nuclear and magnetic structures, J. Appl. Crystallogr. 2 (1969) 65-71.

[16] R. Saferstein, Criminalistics: an Introduction to Forensic Science, seventh ed., Prentice-Hall International, 2001, 576 pp.

[17] P. Boersma, D. Weenink, The PRAAT Principal Component Analysis Software University of Amsterdam, 2003, http:// www.praat.org.

[18] E.P. Junger, Assessing the unique characteristics of closeproximity soil samples: just how useful is soil evidence? J. Forensic Sci. 41 (1996) 27-34. 